\section{Se cruzan los relatos: \\ memoria personal y reconstrucción histórica}

Silvia Dutrénit Bielous

Silvia Dutrénit Bielous es Profesora-InvestigadoraTitular del Instituto Mora, Madrid 82, Del Carmen, Coyoacán, CP. 04100 México, DF. Tel/fax:(5255) 55548946 y 8925.

E-mail: sdutrenit@institutomora.edu.mx

\section{Resumen}

La migración forzada fue uno de los efectos de la represión estatal (con el respaldo de la Operación Cóndor) por la que atravesaron los países del Cono Sur en los años setenta y ochenta. El texto focaliza las peripecias de algunos migrantes políticos que llegaron a México vía distintas disposiciones internacionales destinadas a proteger los derechos del hombre: el asilo diplomático otorgado por el estado mexicano y el refugio brindado por el ACNUR. La narración se realiza a partir de una difícil trama tejida con hilos de la memoria individual de la autora sobre su historia personal y de un relato histórico apegado a los criterios de la disciplina. Para esto último el trabajo se apoya en distintas voces provenientes de los protagonistas de aquellos hechos y en documentos diplomáticos. El texto figura pues como dos relatos en paralelo y arriesga el trabajo "objetivo" de la historiadora confrontándolo con las experiencias y sentimientos de quien vivió las dictaduras recientes en Argentina y Uruguay. En suma, podría considerársele como un texto ubicado en las fronteras disciplinarias de la historia y las ciencias sociales.

\section{Summary}

Forced migration was one of the consequences of the governmental repression (backed by the Operación Cóndor) suffered by the South Cone countries in the 1970s and 1980s. This paper is focused on the vicissitudes of some of the political migrants that arrived in Mexico through different international arrangements oriented to protect the human rights: the diplomatic asylum conceded by the Mexican State, and the refuge conceded by UNHCR. The narration is built from a difficult plot knitted with threads of the author's individual memory about her personal history and from historical accounts based on discipline criteria. For this latter, this work relies on different voices of the protagonists of those events and on diplomatic documents. Thus, the text runs as two parallel narrations and challenges the objective work of a historian by confronting it with the experiences and feelings of those who lived the recent dictatorships in Argentine and Uruguay. Summing up, it could be considered as a text located between the disciplinary boundaries of history and social sciences. 